\author{
Софија Григоријаду, (Грција) \\ Универзитет „Пандио“, Атина \\ е-пошта: jbioskop@gmail.com \\ grigoriadousofia.work@gmail.com
}

\title{
ХЕРОИ НА ПИЕДЕСТАЛИ И „ХЕРОИНИ НА НАШЕТО ВРЕМЕ“ ВО ПАРКОТ „ЖЕНА БОРЕЦ“ КОНФЛИКТНИ ФОРМИ НА КОМЕМОРАЦИЈА И ВИДЛИВОСТ ВО СКОПЈЕ
}

Апстракт: Во текот на последната декада проектот за урбана преродба Скопје 2014 наметна значителни промени во центарот на градот и значително го реконструира културното наследство. Овој проект го утврди, односно го зајакна родовиот концепт на националниот идентитет според кој од жените се бара да обезбедат размножување на нацијата и да бидат мајки на нацијата. Овој текст се фокусира на преговарањето помеѓу официјалното и неофицијалното наследство, сеќавањето и видливоста во последните десет години во Скопје. Текстот ги следи женските и ЛГБТКИА-активисти додека се здружуваат во спротивставувањето на официјалните, алтернативните или субверзивните артефакти на наследството, како и на јавните простори на кои им се припишува неинклузивно значење. За да го направи тоа, текстот ги носи читателите низ јавните простори на Скопје, почнувајќи од северниот брег на Вардар и понатаму до паркот „Жена борец“, во кој, и покрај името што го носи, во моментов има скулптури што ги слават главно машките херои. Во продолжение, текстот ги носи читателите во една посебна дневна соба украсена со портрети на современи хероини. Токму тука и со одредени дополнувања од авторитарното монументално сликарство, текстот ја препознава моќта на сликањето да воодушеви, да обележи и да прослави и во исто време ни открива дека галериското сликарство може да ги протне своите нишки во јавниот простор. Текстот на крајот се враќа во паркот во придружба на двоен портрет со цел да ги истражи практиките на уметниците и активистите во однос на социјалистичките споменици. На крајот се придружува на првата Парада на гордоста во Скопје, која ја следат погледите на мажествените скулптури во паркот.

Клучни зборови: Скопје 2014, јавен простор, споменици, активизам, феминизам, парк „Жена борец“, сликање, уметност, сеќавање.

Првата прошетка низ Скопје: средба со еден сликар и со еден проект за родова реставрација

Скопје го посетив за прв пат во 2014 година, со малку познавања за македонскиот главен град. Ги оставив своите работи во хостел во близина на бруталистичката железничка и автобуска станица и почнав да се шетам кон центарот на градот. Ги преминував широките улици со еднакво широките тротоари, малите 
зелени површини, старите еднокатни или двокатни куќи со градини, додека во далечината можев да забележам неколку високи резиденцијални и деловни згради. Неколку минути откако го сретнав Вардар, околината драматично се промени. Кранови, скелиња и купишта градежен материјал, како и многу згради и споменици со историцистички, еклектичен, а сепак постмодернистички карактер (Koteska 2011) го обележаа мојот влез во центарот каде што проектот Скопје 2014 беше во полн развој.

Урбаната преродба на проектот Скопје 2014 беше развивана, финансирана и спроведувана од страна на македонската влада ${ }^{1}$ во периодот од 2009 до 2016 година. Преку ребрендирање на нацијата што се состоеше од интензивно прикривање на непожелното наследство и откривање ново, проектот се обиде да го привлече приливот на капиталот во неолибералниот свет, но во исто време и да одговори на локалните и меѓународните предизвици со кои се соочуваше земјата уште од својата независност ${ }^{2}$ (Dimova 2013, 2019; Graan 2013; Janev 2015, 2017; Risteski 2016; Ристески 2018; Stefoska, Stojanov 2017). Скопје 2014 се соочи со многу контроверзии и со многу голем отпор (види: Вилиќ 2009, 2015; Гелевски 2010, 2010а, 20106; Теодосиевски 2017). Локалните и странските истражувачи и набљудувачи ја изразуваа својата загриженост посочувајќи, меѓу другото ${ }^{3}$, дека проектот генерира или дополнително ги интензивира постојните етнички, класни и родови поделби (Ahmeti 2011; Dimova 2019; Graan 2013; Kolozova et al. 2013; Koteska 2011; Risteski 2016; Rogoś 2019; Véron 2015). Скопје 2014 беше претставуван како насилна активност против градот и

1 На градот му се случија огромни трансформации што ја редефинираа симболичката околина на Скопје и неговата општествена меморија. Новите споменици беа исполнети со нови ритуали и значења. Проектот претставуваше дел од процесот на „антиквизација“, кој, од една страна, инсистира на историски континуитет со македонското античко минато, а, од друга страна, форсира историцистичка естетска артикулација на европскиот сон (Mattioli 2014; Risteski 2016; Vangeli 2011). Како продолжување (и како интензивирање) на постсоцијалистичката етноцентрична промена, проектот го присвои еклектичниот пристап кон историјата, уметноста и архитектурата. Тој ги имплементираше политиките за чистота прикривајќи го градското социјалистичко и исламско наследство со тоа што ги насочуваше погледите и чекорите на пешаците на друга страна (Ahmeti 2011; Amygdalou 2018; Janev 2015;

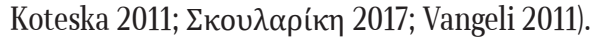

2 Скопје 2014 беше на линија со постсоцијалистичката валоризација на она што се смета за „европско“ (важно е да се забележи дека различни актери имаат различни разбирања за тоа што е всушност европство, што создава различни „режими на естетика“ и различни политики [Mattioli 2014]). Покрај ова, проектот преставуваше обид за омаловажување на грчкиот монопол на македонското минато и одговор на грчката блокада за меѓународно признавање на земјата по нејзината независност во еден период на повторно интензивирање на „македонското прашање“. На крајот, Скопје 2014 се обидуваше да предупреди на предизвиците што произлегуваат од мултиетничкиот состав на Северна Македонија, иако тоа го правеше преку повторно потврдување на веќе постојните релации на моќ, кои уште повеќе ги интензивираа меѓуетничките поделби (Dimova 2013; Graan 2013).

3 Да споменам само неколку: диспропорционалниот трошок за проектот што дополнително ја оптовари економијата на земјата; многумина од локалното население го доживуваа како наметнато түѓо тело на градот и на националниот наратив; генерално негативната меѓународна рецепција на проектот; како и улогата на Скопје 2014 во опструирањето на влезот на земјата во EУ (Graan 2013; Kolozova et al. 2013). 
неговите жители. Наметнатата архитектура беше перципирана како „архитортура“ (Гелевски 2010б), додека жителите протестираа против „силувањето“ на Скопје (не силувајте го Скопје) или против „насилната узурпација“ и „физичка повреда“ на нивниот град, но исто така и против неговата „сексуализација“ според родовото разбирање за националниот идентитет и маскулинистичките вредности што ги промовира проектот (Véron 2017: 142).

На мојата прва прошетка низ Скопје се најдов меѓу многу споменици посветени на личности што во тој момент ми беа непознати. Помеѓу нив една статуа на сликар на северниот брег на Вардар ми го привлече вниманието. Долгата коса на сликарот паѓаше наназад додека тој правеше одлучен чекор напред со неговата палета во раката, една поза што индицира страст и емоција/движење. Мојата прва помисла беше да ја поставам камерата на скалите на соседната зграда и да позирам лице в лице со човекот копирајќи ја неговата поза полна со самодоверба (слика 1). Додека си заминував, почнав да се прашувам што ме наведе да ја направам таа конкретна фотографија пред статуата на личноста што не ја познавав, во град чија историја и култура исто така ми беа непознати.

Првата помисла ми беше дека мојот импулс можеби потекнува од скорешната одлука да се оддалечам од сликањето и да експериментирам со други уметнички изрази, како на пример со звукот, перформансата, со одење и мапирање. Овие медиуми ги гледав како можно решение за мојата потреба да дејствувам надвор од изложбениот простор и на поангажиран начин. Покрај ова, почувствував дека овие медиуми не го носат она што дотогаш го гледав како тешко наследство на сликањето во смисла дека тие не учествуваат во одржувањето на востановените родови улоги и на постојните релации на моќ во иста мера. Тие медиуми не ме потсетуваа на моите позиции во однос на создавањето и репродукцијата на „машкиот поглед“ на сликарското платно (Mulvey 1989). Тие не ме потсетуваа на машките сликари што ги познавав или на оние што го прифатиле погледот, темпераментот и ставот што автоматски му ги припишав на сликарот од статуата во Скопје. Тогаш не знаев дека, неколку години по таа средба, сликањето ќе стане централно во моето теренско истражување за современата уметност и јавниот простор во Скопје.

Како што продолжував да шетам низ центарот, така станував сѐ почувствителна за тоа како градот дејствува врз мене. Мојот избор на таа конкретна поза до статуата веројатно беше мотивиран од целосниот недостиг на статуи што претставуваат жени во таа околина. Единствениот споменик што беше посветен на жена што го сретнав на таа прва прошетка беше всушност комплекс од скулптури посветени на Олимпија, мајката на Александар (или на „Мајките на Македонија“), на влезот на Старата чаршија ${ }^{4}$. Комплексот содржи четири моменти од животот на Олимпија како мајка, славејќи ја не самата кралица или нејзините значајни дела, туку единствено фактот што таа го родила големиот човек. Тематизирајќи го концептот на мајчинство, комплексот ја претставува Олимпија трудна, потоа како го дои малиот Александар, како го гушка или како си игра со него во нејзиниот скут.

4 Овој комплекс е дизајниран од скулпторката Валентина Стефановска, професорка на Ликовната академија во Скопје. 


\section{Паркот „Жена борец“ без жени}

Се вратив во Скопје за моето истражување за докторската дисертација во 2018 година. Комплексот на Олимпија веќе ме испровоцира да размислувам за женската видливост и комеморација во јавниот простор, и затоа го посетив паркот посветен на „жената борец“ неколку пати. Паркот е полн со скулптури и споменици. Најстариот меѓу нив е споменикот според кој е именуван паркот, речиси апстрактна модернистичка мермерна скулптура од Боро Митриќески што ги слави жените што активно учествувале и ги загубиле животите во Народноослободителната борба за време на Втората светска војна. Тој бил откриен во 1970 година од страна на југословенската влада (види повеќе кај Хаџиевска et al. 2021).

Иронично, во рамките на Скопје 2014, паркот „Жена борец“ беше „окупиран“ (Јана Јакимовска, лична комуникација, 2018) од статуи што ги претставуваат мажите ${ }^{6}$. Од приближно дваесет нови скулптури поставени во паркот, само една е во чест на конкретна жена7. Диспропорционалноста на машките и женските скулптури во паркот е тивка насилна материјализација на официјалната нарација на Скопје 2014. Покрај тоа, женските статуи во Скопје на генерално ниво најчесто репрезентираат вредности како што се мајчинството и победата, или некои трендови како (женско) перчење/снобовство ${ }^{8}$, кои се водат од стереотипното маскулинистичко

5 Еден од слоганите што се појави на плакатите за време на протестите против Скопје 2014 во раните 2010-ти години вели: „Паркот на Жената (борец) без жени“. Колумнисти и други коментатори забележаа дека „Жена парк премолчено стана Паркот на мажите“ (Тануров 2012).

6 Помеѓу нив: членови на Антифашистичкото собрание на народното ослободување на Македонија (АСНОМ), првото собрание на земјата по Втората светска војна; револуционери што учествувале во борбите за независност од Отоманската Империја; Пјетер Богдани, албански писател и еден од малкуте споменици на Скопје 2014 посветени на албански личности, по договорот меѓу ВМРО-ДПМНЕ и ДУИ, албанска партија што беше дел од владејачката коалиција (во врска со преговорите меѓу двете етнички политички партии, учеството и репрезентацијата на етнички Албанци во Скопје 2014, или нивното исклучување од проектот, како и за рецепцијата и одговорот на проектот од страна на албанската етничка заедница и албанското политичко лидерство види кај Risteski 2016; Véron 2015). Вклучувањето на неколку антифашистички и албански личности во проектот може да се третира како компромис што ќе му овозможи на ВMPO-ДПМНЕ да ги пресретне обвинувањата за пристрастен пристап кон историјата. Сепак, недалеку од скулптурата на Богдани има еден споменик на мажествени фигури посветен на членовите на македонската армија што ги загубиле животите во конфликтот во 2001 година. Овој конкретен избор на споменик што ги слави Македонците што херојски паднале за својата земја во борбата со албанските бунтовници наместо споменик што ќе изразува помирување ја продлабочува поделбата помеѓу двете етнички заедници (Véron 2015), особено кога е поставен во близина на еден од малкуте албански споменици на Скопје 2014. Во паркот „Жена борец“ исто така има релјеф посветен на македонските деца бегалци од Грција за време на Граѓанската војна на кои никогаш не им било дозволено да се вратат дома, како и споменик на паднатите национални херои со стилска референца на Бранденбуршката порта со робусна скулптура на Прометеј (за скулптурите и комплексите во паркот „Жена борец“ види: Risteski 2016; Skopje 2014 Uncovered n.d.).

7 Веселинка Малинска, дел од комплексот АСНОМ.

8 Како што имплицира насловот и/или прекарот „Шмизла“ на скулптуритешто претставуваат млади, сексуализирани жени што зборуваат на телефон, муабетат или носат ќеси од шопинг. 
разбирање на сексуалноста и привлечноста. Недостигот на комеморација на жената во јавниот простор и во јавната сфера не започнува со Скопје 20149. Сепак, не само националистичкото туку и родовото разбирање на историјата, меморијата, националниот идентитет и јавниот простор што ги манифестира овој проект е уште порадикално, замолчувајќи го женското үчество во овие полиња и отфрлајќи го официјалното препознавање на моќта и знаењето на жените - спротивно на она кон што целеше паркот на „жената борец“ во времето на социјализмот. На овој начин проектот ја засилува востановената родова хиерархија, препознавајќи ги жените како добри мајки и објекти на желба, одржувајќ ја машката доминација во јавниот простор и во јавната сфера (види Milevska 2013; Veljanovska 2018; Véron 2015).

Сите комплекси и статуи во паркот „Жена борец“, подигнати на масивни платформи, се реалистични и преголеми. Тие се наредени наспроти Собранието на улицата „11 Октомври“, една од најпрометните во градот. На овој начин тие го поместуваат како просторно така и симболично речиси апстрактниот и според големината многу помалиот споменик на „жената борец“, кој е поставен подлабоко во паркот и е опколен со дрвја.

Веднаш наспроти паркот се наоѓa македонското Собрание. Во 2013 година Собранието ги изгласало промените во Законот за прекинување на бременоста. Помеѓу амандманите за кои се гласало имало еден што се однесувал на задолжителен период на одлагање на операцијата кога социјален работник би можел да ѝ понуди на жената советување (обесхрабрување за абортусот) додека на бремената жена ѝ се покажуваат слики од фетусот и звуци од неговата срцева акција. Покрај ова, се предвидувале големи казни за докторите што нема да го почитуваат законот ${ }^{10}$. Важноста што владата на ВМРО-ДПМНЕ му ја припишувала на мајчинството може да се посведочи и со фактот што помеѓу најскапите државни рекламни кампањи во периодот од 2008 до 2015 година биле тие што поттикнувале раѓање на трето дете и оние против абортусот ${ }^{11}$. Ваквите политики ѝ служеле на тогашната влада во намерите да ја направат жената потчинета на официјално промовираната улога на

\footnotetext{
Скулптурите на Димитар Филиповски и Александар Иваноски-Карадаре беа откриени во 2009 година пред официјалната инаугурација на Скопје 2014. Некои од моите соговорници ги третираат како дел од проектот, додека други не ги третираат така (Skopje 2014 Uncovered n.d.).

9 Според Сузана Милевска: „Иако за време на педесетгодишниот комунистички режим жените стекнале многу права што го следат нивното јавно присуство, транзицискиот период ги откри слабостите и површноста на (...) родовата еднаквост и фрли светлина врз многу контрадикторности во родовите односи“ (Milevska 2006). За работните услови на жените во уметноста види Milevska 2013.

Недостигот на женската репрезентација во јавниот простор пред Скопје 2014 е забележан во уметничката работа на Христина Иваноска „Именување на невестата“. Кога Иваноска сфатила дека имињата на улиците во Скопје главно слават мажи, таа се обидела (и конечно успеала) официјално да именува еден новоизграден мост по Накие Бајрам и Роса Плавева, Турчинка и Македонка, феминистички социјалистки, и двете активни во Скопје во почетокот и средината на 20 век (Milevska 1998; Иваноска 2005).
}

10 Амандманите беа повлечени во 2019 година со нови измени во законот.

11 Veljanovska 2018. 
мајка, улога од која повторно иронично морале да се откажат „жените борци“, барем на одредено време ${ }^{12}$.

Во споредба со југословенските социјалистички стандарди, во постсоцијалистичките режими се промениле и официјално промовираните женски стереотипи и репродуктивните политики. Имајќи предвид дека мајчинството е популарно третирано како начин за одбрана на државната територија, наметнатите ограничувања на правото на абортус покажуваат дека на жените се гледа како на државна сопственост со тоа што се сведени на ниво на нивната биолошка функција да раѓаат деца (види АӨ ${ }^{2} \alpha \sigma i ́ o v ~ 2010 ;$ Tsagarousianou 1995; Veljanovska 2018; Zajovic n. d.). Сепак, ваквите мерки беа дочекани со отпор во градовите на поранешна Југославија. Во Скопје одговорот на овие амандмани и скапи државни кампањи вклучуваше демонстрации, правни активности и интервенции во јавниот простор со учество на граѓаните и невладините организации за човекови права ${ }^{13}$.

\section{„Хероините на нашето време“ во дневната соба}

Следејќи ја родовата нарација што ја наметнува Скопје 2014 и наметнувањата од измените на Законот за прекинување на бременоста, вистинското место на жената е во нејзиниот дом. Приближно таква претстава добив кога ја посетив самостојната изложба на Јана Јакимовска „Хероините на нашето време“ во Музејот на град Скопје во декември $2018^{14}$. За својата изложба уметницата портретира жени што учествувале во неодамнешните социјални или феминистички борби, на места што тие ги избрале. Очекував дека ќе видам типична сликарска изложба каде што платната ќе висат едно до друго во бела коцка. Сепак, кога влегов во изложбениот простор на музејот, се изненадив поради откривањето на една пријатна аура, спротивно на моите претходни искуства и на дискусиите што ги водев со уметници или куратори, најчесто заклучувајќи дека тоа би било „голем предизвик“ и дека би било „тешко“

12 На пример, Сузана Милевска, како дел од нејзината потрага во балканските фотографски архиви (историски, национални, државни; како и библиотеки и музеи во различни градови низ Балканот), пронашла слики на жени што учествувале во вооружени конфликти за време на Отоманската Империја. Фотографираните жени биле во војнички униформи, опашани со куршуми и со пушки на рамената. Имало многу малку показатели на нивниот род бидејќи имале кратки коси и нивните гради биле скриени зад грубата ткаенина. Независно од причината за да се направат овие фотографии, тие, според Милевска, имаат „неизбежно влијание врз културната меморија, пополнувајќи ја празнината во претставувањето на родовата различност“" (Milevska 2010: 109). Тие сведочат за „двосмисленостите и дисонанците“ (Milevska 2010: 103) во начините на кои се практикувал родот на Балканот за време на Отоманската Империја и ја покажуваат хетерогеноста на репрезентациите дури и во системи што се третираат како строго патријархални.

13 За подетална презентација на настаните види Мишковска Кајевска 2016. За преземените правни активности види: „Новиот Закон за абортус пред Уставен суд“ 2013.

14 Изложбата, чија кураторка беше Елена Вељановска, беше поддржана од Министерството за култура во рамките на Годишната програма за поддршка на уметноста и културата за локалните културни работници. 
поради тоа што просторот има многу долга форма. За изложбата на Јакимовска беше изолиран еден гипсен sид што ја содржеше нејзината инсталација во еден ограничен, квадратен простор. На подот беше поставен црвен тепих, а зидовите беа покриени со шаблонски мотиви што оддаваа впечаток на таписерија. Платната со портретите на жените навистина висеа на зидовите ${ }^{15}$, додека во изложбениот простор беа аранжирани столови, масички и вазни со цвеќиња на нив (слика 2) ${ }^{16}$. Уметницата ми кажа дека сакала просторијата да личи како домашен простор, како соба на некоја стара дама што била активистка во нејзината младост. На зидовите на нејзината соба се портретирани приказни на други жени како неа. Сепак, таа ја определи својата инсталација како „предупредувачка“ (Јакимовска, лична комуникација, 2018). Топлата домашна атмосфера на инсталацијата има цел да предупреди „дека, ако не дејствуваме и ако не ги сместиме овие женски приказни во историјата каде што припаѓaат, тие ќе останат во домашниот домен како и поголемиот дел од женската историја“ (Veljanovska 2018). Читајќ ги овие први редови од текстот на кураторката додека се движев низ изложбениот простор, моето првично чувство за блискост за кратко се претвори во клаустрофобија.

Елена Вељановска, кураторка на изложбата, ја спротивставува анонимноста, невидливоста и домашниот живот на женските приказни со официјалната промоција на нови (машки) херои и со продукцијата на колективната историска меморија во контекст на Скопје 2014. Таа зборува за интензивирањето на таквите државни интервенции во јавниот простор и јавната сфера како „нов култ на хероизација“. Во еден „естетски режим“ (види Mattioli 2014) што создава исклучиво машки херои, проектот Скопје 2014 и неговиот „ретрограден, маскулинистички (...) симболизам (...) ја сведува улогата на жената на една нејзина основна биолошка функција“ (Veljanovska 2018). Иако женската комеморација во градот беше минимална и пред Скопје $2014^{17}$, феминистичките борби во однос на јавната видливост се интензивираа дури по имплементацијата на проектот. Тоа се случи во рамките на протестите против полициската бруталност и против узурпацијата на јавниот простор во контекст на Скопје 2014, кога се разви еден „нов бран на феминизам“ (Veljanovska 2018). Јакимовска и жените што ги портретирала активно учествувале во овој бран.

\section{Назад кон сликањето: комеморација и фасцинација}

Работата на Јакимовска што ми беше позната кога ја посетив нејзината изложба главно содржеше колажи што вклучуваат пишување, резбање и сликање на слики преземени или нејзини. Реферирајќи на селфи, на културата на социјалните мрежи и на поп-културата, таа коментира за современите теми од една феминистичка перспектива. Уметницата ми кажа дека не сликала подолго време пред серијата со

15 Краток текст беше ставен под секое платно со името на портретираната жена, каде е портретирана и зошто, објаснувајќ ги причините зошто Јакимовска ја смета жената за „хероина“.

16 Фотографија на Драгица Николовска („Хероините на нашето време“ 2018).

17 Види фуснота број 9. 
„хероините“. Сликањето за неа не изгледало како вистински медиум во рамките на радикалниот развој во претходната декада во Скопје. Таа почувствувала потреба да го напушти изолираниот простор на работилницата со цел да учествува во протестите и во други колективни форми на активизам и на уметничка експресија во јавен простор ${ }^{18}$ (Јакимовска, лична комуникација, 2018). Помеѓу нејзините самостојни дела од тој период се наоѓa една серија од автопортрети изработени со комбинирани медиуми со наслов „Божем ќе сликав но... “919. За секое дело реченицата е комплетирана со причината зошто не сликала: „,...но се почувствував <3“, ,...но има бунт“, ,...но сега е 2014“ итн. За последното уметницата се поставила себеси како гола скулптура на еден класицистички постамент, веројатно со монументална големина (според тоа што таа е опкружена со небо, птици и облаци), посочувајќ на огромните машки скулптури што го окупираа Скопје во тој период. Во 2019 година, откако револуцијата во градот стивна, таа избира да ги претстави своите хероини преку реалистично сликарство, медиум што широко се користи за комеморација низ (западната) историја. Сликањето повторно станува соодветен начин за уметничка експресија, кое ќе ги донесе во преден план „хероините“ што учествувале во борбите. Како уметница што исто така се дистанцирала од сликањето, овој пресврт ме стимулира да истражувам.

Кога ја прашав Јакимовска за нејзините критериуми за избор на конкретни жени чии портрети се вклучени во изложбата, таа ми кажа дека нејзината првична листа била многу подолга, но буџетот на изложбата не дозволувал повеќе ${ }^{20}$. Таа потенцира дека во секој случај оваа изложба не претендирала да стане исцрпен каталог на хероини или енциклопедиски документ за оние што учествувале во феминистичките или социјалните борби од тоа време. За неа било полесно да вклучи жени со кои претходно се познавала. Најмногу од практични причини, првата група портрети што испланирала да ги направи како дел од проектот „Хероините на нашето време“ биле главно нејзини пријателки (Јакимовска, лична комуникација, 2018 и 2021). На мое изненадување, посетителите го критикуваа изборот на портретирани жени од блискиот круг на уметницата и покрај фактот што уметноста се разликува од архивирањето или историографијата - независно од нејзините можни придонеси во овие полиња. Покрај тоа, следејќи го развојот на күлтурната критика, феминистичките студии и постколонијалната теорија, уметниците не можат веќе да се повикуваат на универзалноста или објективноста (ако некогаш воопшто можеле); тие единствено зборуваат од нивната сопствена позиција, за нив самите и за начините преку кои се поврзуваат со другите луѓ и со другите нешта (види на пример: Foster 2002; Gouma-Peterson, Mathews 1987; Korsmeyer, Brand Weiser 2021).

18 Таа учествуваше во активистичкиот хор Распеани скопјани и периодично во други колективни проекти, како на пример Кооперација, група уметници што изложуваат критичка уметност во неинституционални простори.

19 Серијата беше изложена меѓу 2014/2015 година во самостојна или во групни изложби во Северна Македонија и во странство, во независни простори, но исто така и во државни институции.

20 Според дискусиите со многу уметници во Скопје, апликациите за поддршка на уметнички и културни проекти избрани од Министерството за култура најчесто не ја добиваат целосната сума со која аплицирале. Од уметниците честопати се бара да ги приспособат своите проекти на буџетот. 
Во обидите да ги контекстуализирам или разберам критиките за неинклузивност, јас барав причини во хроничното чувство на немоќ и исклученост од процесот на носење одлуки што го носат многумина од моите соговорници во Скопје (види исто: Dimova 2013). Во секој случај, критиките на изложбата на Јакимовска овозможуваат увид во тоа како дејствува уметноста врз нејзината публика. Како што веќе знам преку мојата работа како уметница и наставник, вештото реалистично сликање продолжува да ја воодушевува публиката, создава восхит за личноста што има такви технички вештини, како и за насликаното платно што ја отелотворува таа вештина (Gell 1992). Сликањето изгледа дека и денеска ја избегнува демистификацијата. Сѐ үште е широко прифатено како „достоен“ медиум што претставува (и треба да претставува) еднакво достојни и важни работи, личности и настани. Покрај тоа, моќта на сликањето да документира, да слави и да глорифицира изгледа непроменета во светлината на критиките на работата на Јакимовска - дури и во време кога фотографијата и видеото уште одамна ја замениле неговата документаристичка употреба. Во таа иста светлина, границата помеѓу уметноста и историографијата може често да се третира како нејасна. Според едно подинамично и поотворено разбирање на спомениците, може да се каже дека тие не постојат исклучиво како конструкции или аранжмани во јавниот простор (Гı $\alpha \lambda$ oúpๆ 2010). Во таа смисла, на површината на платното може исто така да ѝ се пристапи како на потенцијално монументален простор.

\section{Лажна уметност или „социјалистички реализам без социјализам“21}

На поранешната власт ѝ била позната восхитувачката моќ на сликањето - и на споменичната уметност воопшто, како што веќе покажав во случајот со скулптурите на Скопје 2014 - како и вековната употреба на уметноста за комеморациски и глорификациски цели. Во 2016 година се појави серија реалистични маслени слики со монументални димензии на зидовите на новоизградената палата „Христо Татарчев“ каде што и денеска се наоѓаат челниците на партијата ${ }^{22}$. Сликите ги претставуваат важните личности и славните моменти од поновата историја на партијата (слика 3).

Уметниците и други критичари ги третираат овие слики како оживување на култот кон лидерот, само сега во постсоцијалистичко време и во рамките на националистичката агенда. Тие го споредуваат стилот на сликите со тој од социјалистичкиот реализам и заклучуваат дека портретите на ВМРО-ДПМНЕ се „мутација“ на тој жанр „во која е задржан реалистичниот израз, но го нема среќниот

21 Од насловот на текстот „Македонската владејачка партија го оживеа социјалистичкиот реализам без социјализмот“ на Филип Стојановски (2016) („Macedonia’s Ruling Party Has Resuscitated Socialist Realism Without the Socialism“ by Filip Stojanovski, 2016).

22 Беа порачани многу слики со историски теми за да се опремат два новоизградени музеи во рамките на проектот Скопје 2014, главно за Археолошкиот музеј (2012) и за Музејот на македонската борба за самостојност и независност, мүзеј на ВMPO и музеј на жртвите на комунистичкиот режим (2011) денеска преименуван поради политичка коректност како Музеј на македонската борба. 
работник“ (Богдановски во Георгиевски 2016)23. На некои слики граѓаните се појавуваат сместени на рабовите на платното, оставајќи го центарот - и симболичката тежина - на партиското водство. На ова би додала дека сликите се продолжување на градската родова прераспределба бидејќи поголемиот дел од насликаните луѓе се мажи. Носејќи го нивниот критицизам үште понатаму, неколку критичари, како и многумина од уметниците со кои зборував го ставаат под прашање статусот на портретите на ВMPO-ДПМНЕ како уметност, како што прават со целиот проект Скопје 2014 (види на пример: Богдановски во Георгиевски 2016; Tahiri во Jakov Marusic 2016). Целта на овој текст не е да утврди дали овие портрети се уметност или не и според која теорија. Она што е важно да се забележи, според мене, е дека непризнавањето на овие слики и скулптури како уметност е можеби стратегија за непризнавање и дискредитирање на целиот режим и неговите вредности: промените што ги наметна на градот се осудени како штетни за квалитетот на секојдневниот живот на граѓаните и за меѓународниот имиџ на земјата, а тоа беше главно припишувано на создавањето и промоцијата на „лажна“ национална нарација (Graan 2013) и, како што изгледа, преку продукцијата на еднакво „лажна“ уметност.

\section{Во мејнстримот}

Она што е сигурно е дека артефактите како овие слики имаат влијание врз граѓаните и најчесто влијаат на еден насилен начин. Граѓаните најчесто реагираат преку изјави, протести и преку уметност. Јакимовска почувствувала дека сликањето како уметнички медиум што нејзе иे е драг „било украдено и исмевано“ од страна на „пропагандните портрети“ на ВМРО-ДПМНЕ. За неа „Хероините на нашето време“ е проект што меѓу другото се обидува да „го врати достоинството“ на нејзиниот медиум (Јакимовска, лична комуникација, 2018; Veljanovska 2018). Сликањето им служело на моќните низ вековите, од европските кралски судови на просветителството до нацистичките режими. Како што е случај со сите уметнички медиуми, и тука е клучна позиционираноста: кој слика, од која позиција и за кого. Спротивно на владините портрети што вклучуваат најчесто мажи, изложбата на Јакимовска портретира женски „хероини“ (види на пример: слика 4), кои се исклучени од официјалната меморија. Покрај тоа, таа ја превртува не само патријархалната содржина на портретите на ВМРО-ДПМНЕ туку и нивната монументалност: нејзините дела се многу помали според големината; околината во која се појавуваат жените е од нивниот секојдневен живот; слично како и во другите нејзини проекти, субјектите не се идеализирани или разубавувани, ниту се сместени во некакво „херојско“ дејство или славен настан. Естетските избори на сликарските платна на еден сетилен начин фрлаат светлина на мотивите, желбите и начините на кои луѓето и институциите вклучени во нив ги доживуваат и дејствуваат во однос на градот, наследството и јавната меморија. И покрај нивните разлики, стилскиот избор на реалистични слики во кои карактеристиките на избраната личност се појавуваат чисти мислам дека е

23 Види исто кај: Котеска 2016; Георгиевски 2016; Stojanovski 2016; Radisic 2014. За споредба меѓу Скопје 2014 и социјалистичкиот модернизам види Dimova 2019. 
од клучно значење како во сликите од палатата Татарчев така и во портретите на Јакимовска. И едните и другите се направени за да слават одредено сеќавање; со цел да го утврдат или да го одржат статусот на луѓето - или настаните, во случајот со поранешната влада - како вреден за сеќавање. Судејќи според бројот на улиците, скулптурите и сликите што ги слават мажите, може лесно да се заклучи дека женските приказни вообичаено се игнорираат бидејќи се оценети како помалку важни (види исто Иваноска 2005). „Хероините на нашето време“ се обраќаше на исклучувачките официјални политики за јавна комеморација преку претставување на женските приказни „во мејнстримот“ (Јакимовска, лична комуникација, 2021) низ лесно воочливите и влијателни средства на реалистичното сликарство.

Преку овој краток преглед и спротивставување на портретите на Јакимовска и платната на ВМРО-ДПМНЕ, една уметност како сликањето губи и го враќа достоинството, слави, идеализира, помирува и глорифицира поединци и влади преку прашањето на меморијата во естетска и политичка смисла. Досега тврдев дека сликањето, иако често се третира како застарен медиум, сѐ уште носи значаен симболички капитал и (социјално развиен) активистички капацитет. Освен тоа, и покрај фактот што сликите што ги разгледувам тука се наменети за да висат во галерија - или на некое место - sид, тие, всушност, исто така навлегуваат и во јавниот простор. Луѓето и институциите што ги нарачале или што ги создале портретите, како и оние што се портретирани на сликите на Јакимовска и на ВМРО-ДПМНЕ, биле многу вклучени во јавниот простор во Скопје: дали преку утврдување (или преку придонесот во утврдувањето) на естетскиот режим наметнат преку Скопје 2014 или преку учество во борбата за еден град што ќе дозволи еднакво вклучување на оние што се сметаат како помалку граѓани според вредносниот систем на проектот, како што се жените и ЛГБТКИА. Следејќи една од овие слики, ќе се преместиме од дневната соба во паркот.

\section{Практики на отпор во паркот „Жена борец“}

\section{а. Здружувања и континуитети}

Со оглед на неговата локација наспроти Собранието, паркот „Жена борец“ најчесто е почетна или крајна точка за протести (или контрапротести) или за јавни активности, кои може да траат со денови или месеци, без оглед на политичката припадност. За време на имплементацијата на проектот Скопје 2014, паркот не само што беше место за протест туку тој исто така понуди и материјал за рефлексија во врска со позицијата на жените во Северна Македонија денеска.

Од сликите на Јакимовска од серијата „Хероините на нашето време“ посебно ме заинтересира еден двоен портрет на актерката Кристина Леловац и на антропологот Јана Коцевска, кои позираа пред споменикот на „жената борец“ каде што биле особено активни и лично вклучени во феминистичките борби во градот (слика 4). Леловац и Коцевска се основачки на Tiiiit! Inc., организација што промовира женски права, интелектуална и културна продукција и активизам. Tiiiit! Inc., била создадена во почетокот на 2011 година како одговор на заканите за женските права како резултат на законите што ги споменав претходно. Во рамките на Tiiiit! Inc., 
но исто така и во соработка со други групи, тие организирале и учествувале во активности во паркот „Жена борец“, кој, и покрај трансформацијата со Скопје 2014, сѐ уште е место за зајакнување на жените и за јавен протест.

Во сликата на Јакимовска, текстурата и геометриските форми на споменикот се прелеваат во облеката на двете жени. Според уметницата, ова било чисто естетски избор. Сепак, несвесно или не, на платното е материјализирана една силна врска меѓу борците од минатото и денешните активисти, провоцирајќи го размислувањето за континуитетот на борбите. Врските меѓу современите (антикапиталистички и антинационалистички) борби и оние од социјалистичкото минато се многу чести во постсоцијалистичките режими на поранешна Југославија (фуснота 6p. 25; Mattioli 2014). Напорите да се замолчи и затскрие социјалистичкото наследство во Скопје резултираа со навраќање на тоа наследство во сеќавањата на граѓаните и во јавната сфера ${ }^{24}$. Тоа може да се заклучи не само преку изборот на конкретниот споменик како вистинско место за портретите на Леловац и Коцевска туку и преку континуитетот, дури и интензивирањето на феминистичките (и подоцна и ЛГБТКИА) настани и активности на истото место, по проектот Скопје 2014. Граѓаните го зачувуваат и го активираат социјалистичкото модернистичко наследство преку јавни дискусии, публикации и изложби од областа на архитектурата, како и преку активистичките интервенции. Не е случајно, на пример, тоа што македонскиот павилјон на венециското Биенале за архитектура во 2014 изложувал модели од југословенската модернистичка архитектура од Скопје (Ана Ивановска-Дескова, лична комуникација, 2018; Ивановски et al. 2015). Начините за поврзување со спомениците и изборот на споменици со кои ќе се поврземе не се задолжително диктирани од властите и од

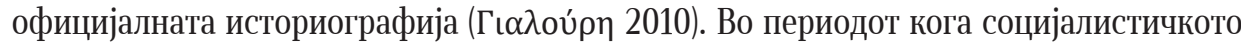
наследство беше затскривано зад историцистичките фасади и згради, поврзувањето со него претставуваше една форма на отпор.

Портретот на Леловац и Коцевска пред споменикот ме потсети на едно видео на активистичкиот хор Распеани скопјани ${ }^{25}$ што го гледав на Јутјуб на почетокот на

24 Види исто Forty, Küchler 2001 за тоа како отстранувањето на спомениците на Ленин од нивните пиедестали во постсоветска Москва всушност го интензивира сеќавањето на нив.

25 Активистичкитехоровикакоформанаотпорикакоестетскипроцессечестивопоранешните југословенски држави. Во однос на неолиберализацијата на постсоцијалистичките општества и генералното разочарување во врска со үчеството во носењето одлуки по распаѓањето на федерацијата во 1990-тите години, активистичките хорови станаа една форма за колективна акција и социјална непослушност, која промовира колективно пеење како политички акт, користејќи хумор и иронија. Тие често ги оживуваат, ги адаптираат и ги пренаменуваат песните од антифашистичкото или социјалистичкото музичко наследство (Hofman 2020), со трага на носталгија. За поединците од поранешните јүгословенски режими, „јүгоносталгијата“ често станува „политичка изјава“ и, според үчесниците во хоровите, придонесува во оформувањето на заеднички политички идентитет (Balunovic 2020). Следејќи ја афективната промена во хуманистичките науки што ги потенцираат пред-, екстра- и паралингвистичките елементи на комуникација, звукот има афективен капацитет за „култивирање на алтернативни начини за социјабилност и нови форми на политичка и културна продукција“ (Hofman 2020: 92). (Перформативноста и емоционалниот набој сепак не се користат само од активистичките хорови. Антропологот Љупчо Ристески зборува за владината перформативност и нејзиниот недвосмислен формалистички и ритуалистички јазик во контекст на официјалните церемонии 
моето истражување. Јакимовска исто така пее во хорот. На 8 Март 2010 година, на меѓународниот ден на жената и за време на периодот кога беа активни кампањите против абортусот и кога беше претставен проектот Скопје 2014, Распеани скопјани ја пееја песната „Она се буди“ (1981) на Шарло Акробата пред споменикот на „жената борец“:

Луѓето се чудат зарем таа може да мисли.

Луѓето се чудат зарем таа смее да знае.

Луѓето се многу злобни додека иे ги гледаат градите.

Луѓето се злобни додека го гледаат нејзиниот тен. ${ }^{26}$

На настапот фразата „таа нема кој да ѝ каже ти си моја“ беше променета во „таа нема кој да ѝ каже ти си своја“, посочувајќи на правото на жената на своето тело. Во текстот што оди на видеото со перформансата поставена на социјалните мрежи ${ }^{27}$ хорот експлицитно ја поврзува интервенцијата со кампањата против абортусот и со Скопје 2014. Во видеото (Plostad Sloboda 2010) споменикот на „жената борец“ со специјална публика направена од камен се појавува во истата рамка зад хорот. Не само што функционира како заднина за интервенцијата туку исто така претставува и потсетник за континуитетот на сегашните активности со социјалистичкото феминистичко минато, мотивирајќи ги гледачите да „ја разбудат жената борец“ во себе. Распеани скопјани се вклучија во многу специфични интервенции низ градот во кои зборовите на песните и нивната кореографија беа своевиден коментар на секоја локација. Тие често настапуваа пред споменици и згради поврзани со Скопје 2014 иако не секогаш се идентификуваа со околината. Напротив, нивната иронична и хумористична изведба ги контаминираше (како кај Douglas 2005) местата што требаше да изгледаат прекрасни, чисти и вечни. Тие дефинитивно придонесоа во деглорификацијата и во трансформацијата на значењата на овие места преку нивната интеракција со минувачите, но исто така и преку широката дистрибуција

што се случуваа во центарот на Скопје, активирајќи нови споменици. Таквите ритуали целат не само кон легитимизирање на авторитетот туку исто така и кон култивирање на чувството за солидарност и заедништво, особено кога консензусот е слаб [Ристески 2018; Kertzer 1988]). Активистичките хорови кратко ги прекинуваат секојдневните урбани рутини бидејќи ги присвојуваат урбаните простори со цел да се обратат честопати на случајна публика што станува учесник во активноста. Види исто Mattioli 2014.

Во Скопје, покрај Распеани скопјани, повеќе уметници и групи, како Ѓоѓ⿱ Јовановиќ и Свирачиња, ја користат музиката и пеењето како уметнички медиум за подигнување на свесноста околу промените што му се случија на градот во последната декада (Jovanovik n.d.).

26 Ljudi se čude zar ona može da misli.

Ljudi se čude, zar ona sme da zna.

Ljudi su vrlo zlobni dok gledaju njene grudi.

Ljudi su zlobni dok gledaju njen ten.

27 Освен перформансите во живо, присуството на социјалните медиуми беше од голема важност за Распеани скопјани со оглед на тоа што нивните интервенции во градот беа засилени преку интернет. Социјалните медиуми и блоговите генерално играа голема улога во ширењето на поинакви информации во време кога мејнстрим-медиумите го пласираа единствено официјалниот дискурс за Скопје 2014 (Çavolli 2012; Marchevska 2017; Marchevska et al. 2017). 
на нивните видеа за што придонесоа и медиумите што се противеа на нивните активности (Јакимовска, лична комуникација, 2018).

\section{б. Хероите на пиедестали набљудуваат одгоре}

Жителите на градот го замислуваат, го присвојуваат и го користат јавниот урбан простор на начини што можат да се разликуваат од оригиналните планови на властите. Јавните протести ја нарушуваат вообичаената функција на урбаните простори и отвораат можности за односи што можат да доведат до косоздавање на репрезентации, сеќавања и приказни што се алтернативни во однос на едностраното и јасното доминантно значење што му е официјално наметнато на градот, како во

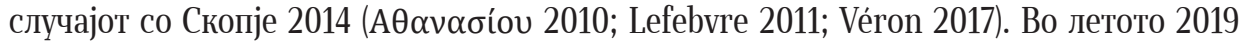
година, учесниците на првата Парада на гордоста организирана во земјата се сретнаа во паркот „Жена борец“. Јакимовска, која исто така е активна во феминистичките и ЛГБТКИА-борби и е повеќеслојна уметница, беше една од клучните изведувачи на парадата, како и трансвеститот Линда Социјалиста (нејзиното име е индикативно за современите референци кон социјализмот во рамките на уметноста и активизмот разгледани претходно во текстот). Јакимовска ми кажа дека почетната точка на парадата во паркот „Жена борец“ била очигледен избор поради „инклузивната женска енергија“ со која се поврзува паркот и споменикот (Јакимовска, лична комуникација, 2021). Од друга страна, јас пристигнав во градот во еден период кога во паркот повеќе немаше многу женски протести, туку најчесто беше активиран од протести против промената на името и против Преспанскиот договор. Ова го направи моето доживување на местото значително различно. Бидејќи не бев во можност точно да се поврзам со неговата „женска енергија“, ги набљудував контрадикциите помеѓу естетиката на парадата и естетиката на маскулинистичките скулптури што беа тука поставени во изминатата декада. Сјајот, разнобојните облеки, знамиња и коси што го преплавија паркот „Жена борец“, квировската перформативност на настаните генерално беа во изненадувачки сетилен контраст со цисродовата машкост, со монументалноста, вертикалноста, ограничената палета, како и со тежнеењето за безвременост со кои зрачеа околните статуи.

Периодот кога скулптурите на Скопје 2014 беа во центарот на официјалната идеологија беше завршен, барем во тој момент. Конечно, поради тоа беше безбедно да се организира Парадата на гордоста. На парадата беа присутни претставниците на амбасадите и на меѓународните организации за човекови права, како и организаторите на паради од соседните земји. На крајот настанот имаше поддршка и присуство од социјалдемократската влада (СДСМ) и од полицијата. Сепак, она што се изведуваше, што се тврдеше и се славеше на парадата е далеку од тоа да биде целосно легално утврдено (не се дозволени истополови бракови и посвојување деца, ниту пак комерцијално сурогатство, меѓу другите ограничувања). Покрај тоа, еден значителен дел од локалното општество сѐ уште е непријателски настроено. За време на првата парада, низ земјата парадираа и „горди“ хетеросексуални семејства со колички за бебиња, со крстови и со национални знамиња во протестите против парадата. Според учесниците од свештенството, „нашето општество е заразено и навистина му е потребна операција. Треба [...] да се отсечат тие тела коишто се гангрена на нашето општество“ (Тера ТВ 2019, 2’30“). Колку и да е шокантно ова 
тврдење, сепак ја потврдува сериозната субверзивна „загадувачка“ закана ${ }^{28}$ што ја носат квировските тела за доминантните хетеронормативни стандарди. Од друга страна, употребата на болеста како метафора (Sontag 2002) за репродуцирањето на родовата дискриминација и нормализација и како можен повик за насилство против квировските тела укажува на нивната ранливост и на недостигот на безбедност што сѐ уште го доживуваат. Сепак, кураторскиот текст од Викендот на гордоста од 2019 година сугерира точно тоа: „да засјаат нечии рани“ повторно присвојүвајќи ги хегемонистичките дискурси на насилство и стигма „за целите на отпор, борба и радикално преозначување и одново превоспоставување на нормативните хоризонти“ (Dimitrov 2019).

Подоцна тој ден, додека бев дома, налетав на една слика од парадата поставена на социјалните мрежи од Хелсиншкиот комитет за човекови права, која на многу моќен начин го резимира моето искуство во паркот „Жена борец“. На неа две насмеани учеснички разменуваат бакнеж под навидум паноптичкиот поглед на големата машка скулптура во паркот „Жена борец“ (слика 5; Skopje Pride 2019). Сликата многу јасно ми се всади во меморијата. Често се прашувам дали овој „поглед“ изгледа како потсетник дека патријархалните и националистичките претпоставки што ги носат спомениците на Скопје 2014 остануваат длабоко вкоренети, фрлајќи сенка на видливоста, комеморацијата, па дури и на безбедноста на жените и на ЛГБТКИА-заедницата. Од друга страна, спротивставувањата во јавниот простор како на сетилно така и на симболичко ниво, како она што е точно фатено и одредено од фотографијата, може да функционираат на субверзивен начин. Ирелевантно е дали се случиле намерно или спонтано, тие дозволуваат „ресигнификација“ на местата на официјалната меморија. Ваквите спротивставувања може да бидат уште една форма на комеморација што ги предизвикува и им се спротивставува на доминантните комеморации.

\section{Заклучок}

Во текстот зборував за специфични моменти од женските и ЛГБТКИАпретензии на комеморација и видливост во јавниот простор и сфера за време на последната декада во Скопје. Исто така се фокусирав и на начините на поврзување и раскинување со постојните споменици и артефакти од социјалистичкиот и постсоцијалистичкиот период. Текстот се однесува главно на паркот „Жена борец“, но исто така накратко го посетивме северниот брег на Вардар и дневната соба на некој замислен иден активист.

Во градот „окупиран“ од споменици во чест на мажите, изгледа дека е круцијално за поединците и групите што се појавуваат во овој текст да бараат различни начини во справувањето со сеќавањата, видливоста и наследството. Низ текстот ги набљудував и дискутирав за обидите да се предизвикаат официјалната (или во некои случаи поранешната, но сѐ үште присутна) естетика и официјалниот

28 За сјајот како контаминирачка закана види Sofia Grigoriadou, Panteion University, 136 Andrea Syngrou Avenue, Athens 17671 
политички режим, како и тактиките и стратегиите за воспоставување нови начини за справување со постојните споменици и со начините на комеморација. Ваквите односи дозволуваат да се појават отпори, здружувања, несогласувања и асоцијации (во двете значења на зборот) што им даваат нови форми и значења на местата на сеќавање (без оглед дали се места во јавниот простор или е тоа површината на платното), преку збогатување или нивно „контаминирање“ со нови приказни и нови значења. Сепак, за спомениците постојано се преговара, и тие постојано се узурпираат. Дури и кога се разбираат како вечни, тие неизбежно стануваат „реален немир, колебање, флуктуација и флексибилност и сѐ она на што всушност се спротивставуваат“"

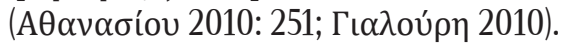

На крајот сакам да се вратам на северниот брег на Вардар во 2014 година. Всушност, таа конкретна слика на бакнеж пред монументалната скүлптура за време на Парадата на гордоста во Скопје (слика 5) ме потсети на мојата заборавена фотографија лице в лице со сликарот чие име можеби и намерно сум го заборавила (слика 1). Со таа фотографија јас спонтано се обидов да направам спротивставување меѓу моето тело и фигурата што ја поврзав со еден специфичен вид на авторитет кон кој бев сѐ покритична. Тогаш за мене беше значајно низ оваа конкретна поза да ги споделам моите мисли што ги носев со себе од Атина и нештата што почнував да ги доживувам во Скопје. Тоа ме тера да помислам дека начините на кои некој се поврзува со спомениците и со наследството се многу комплексни и повеќеслојни. Покрај тоа, кога ја направив фотографијата, јас бев сѐ уште турист во Скопје што доаѓа од Грција. Последново е комбинација што ја става фотографијата на лабава основа и може да донесе недоразбирања. Допрва ќе видиме дали и како ќе ја искористам оваа слика во понатамошните размислувања, активности и рефлексии за (субверзивната) јавна комеморација и за позиционираноста.

\section{Литература}

А.Б. 2014. '(ФОТО) Матка Постави Розов Споменик Во „Жена Парк“ За Правата На Жените'. А1он (blog). 31 мај 2014. https://a1on.mk/macedonia/foto-matka-postavirozov-spomenik-vo-zhena-park-za-pravata-na-zhenite/.

Вилиќ, Небојша. 2009. Силувајте го Скопје! Кн. 1. Скопје.https://zaum.mk/wp-content/ uploads/2017/11/2009 1201 Siluvajte go Skopje.pdf .

Вилиќ, Небојша. 2015. Силувајте го Скопје! Кн. 2. Струга, Скопје.https://zaum.mk/wpcontent/uploads/2017/11/2015 1201 Siluvajte go Skopje.pdf.

Гелевски, Никола, ур. 2010. 13 автори. Неред и гротеска: Разговори и сатири за проектот „Скойје 2014“. Едиција Градот, кн. 1. Скопје: Темплум. 


\section{ЕтноАнтропоЗум}

Гелевски, Никола, ур. 2010а. 14 автори. Крадат град! Зборник текстови за проектот „Скойје 2014“. Едиција Градот, кн. 2. Скопје: Темплум, Плоштад Слобода.

Гелевски, Никола. 2010б. Архитортура \& гробализација: Текстови за градот. Едиција Градот, кн. 3. Скопје: Темплум, Плоштад Слобода.

Георгиевски, Борис. 2016. „Соцреализмот на ВМРО-ДПМНЕ: Народот како толпа која го следи големиот водач“. DW.COM. 2.6.2016. https://www.dw.com/ mk/\%D1\%81\%D0\%BE\%D1\%86\%D1\%80\%D0\%B5\%D0\%B0\%D0\%BB\%D0\%B8\%D0\%B7\%D0\%BC\%D0\%BE\%D1\%82-\%D0\%BD\%D0\%B0-\%D0\%B2\%D0\%BC\%D1\%80 \%D0\%BE-\%D0\%B4\%D0\%BF\%D0\%BC\%D0\%BD\%D0\%B5-\%D0\%BD\%D0\%B0\%D1 \%80\%D0\%BE\%D0\%B4\%D0\%BE\%D1\%82-\%D0\%BA\%D0\%B0\%D0\%BA\%D0\%BE\%D1\%82\%D0\%BE\%D0\%BB\%D0\%BF\%D0\%B0-\%D0\%BA\%D0\%BE\%D1\%98\%D0\%B0\%D0\%B3\%D0\%BE-\%D1\%81\%D0\%BB\%D0\%B5\%D0\%B4\%D0\%B8-\%D0\%B3\%D0\%BE\% D0\%BB\%D0\%B5\%D0\%BC\%D0\%B8\%D0\%BE\%D1\%82-\%D0\%B2\%D0\%BE\%D0\%B4\%D0 \%B0\%D1\%87/a-19300332.

Ивановски, Јован, Ивановска-Дескова, Ана, Десков, Владимир, Каранаков, Бојан, Марина, Огнен, Мицковски, Горан, Радевски, Александар. 2015. Наоди:

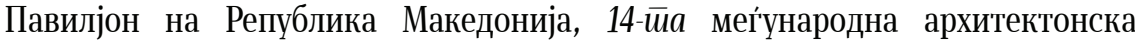
изложба, Биенале во Венеција 2014. Скопје: Младински културен центар.

Иваноска, Христина. 2005. „Роса Плавева и Накие Бајрам“. Форум 162, 95-97, јули 2005. https://www.opafondacija.org/zaum/wp-content/uploads/2018/12/2005 0700 Rosa Plaveva i Nakie bajrami.pdf

Котеска, Јасна. 2016. „Од окултизмот до соцреализмот и назад“. DW.COM. https://www. dw.com/mk/\%D0\%BE\%D0\%B4-\%D0\%BE\%D0\%BA\%D1\%83\%D0\%BB\%D1\%82\%D0\% B8\%D0\%B7\%D0\%BC\%D0\%BE\%D1\%82-\%D0\%B4\%D0\%BE-\%D1\%81\%D0\%BE\%D1\%8 6\%D1\%80\%D0\%B5\%D0\%B0\%D0\%BB\%D0\%B8\%D0\%B7\%D0\%BC\%D0\%BE\%D1\%82\%D0\%B8-\%D0\%BD\%D0\%B0\%D0\%B7\%D0\%B0\%D0\%B4/a-19306149.

Мишковска Кајевска, Ана. 2016. „Закон за прекинување на бременост од 2013 година: Јасна слика за укинувањето на демократијата во Македонија“. Претставено на 24. IPSA, Светски политиколошки конгрес, Познањ._http://hera.org.mk/wp-content/uploads/2016/09/Ana-M-Kajevska-Abortus-Ukinuvanje-na-demokratijataMK.pdf.

„Новиот Закон за абортус пред Уставен суд“. 2013. Академик. 27.9.2013. https://akademik.mk/noviot-zakon-za-abortus-pred-ustaven-sud/. 
Ристески, Љупчо С. 2018. „'Порта Македонија‘, од псевдокласицизам до споменик на културата, од политичка ритуализација до граѓанска демистификација“. Poznańskie Studia Slawistyczne 13, 279-300.https://doi.org/10.14746/pss.2017.13.17.

Тануров, Димитар. 2012. „Паркот Жена Борец стана Паркот на Мажите“. Идивиди, 9.6.2012. http://m.idividi.com.mk/News.aspx?IDNews=776717.

Теодосиевски, Златко. 2017. Што е „Шарената револуција“?. Скопје: Нова линија. zaum.mk/wp-content/uploads/2017/05/2017-01-00_Zlatko-Teodosievski_Sto_e_ sarenata_revolucija_New_line-Skopje.pdf

Хаџиевска, Ивана, Ивана Драгшиќ, Јана Коцевска. 2021. Нашиот пат: 25 женски приказни од историјата. Скопје: Приватен Принт.

„Хероините на нашето време: Интервју со Јана Јакимовска“. 2018. Медуза (блог). 14.12.2018. https://meduza.mk/fem-101/heroinitenanashetovremeinterv\%d1\%98u so\%d1\%98ana\%d1\%98akimovska/.

Ahmeti, Safet. 2011. „Desperately Seeking Europe“. Paper presented at Visualizing Europe: Geopolitical and Intercultural Boundaries of Visual Culture: The 2nd Visual Cultures in Europe Meeting. Barcelona: 11 December 2011.

Amygdalou, Kalliopi. 2018. „'Skopje 2014“ and the return of history“. The future as project, edited by Kalliopi Amygdalou, Kostas Tsiambaos and Christios Georgios Kritikos. Athens: Hellenic Institute for Architecture, 151-167.

Balunovic, Filip. 2020. „'Living Yugoslavia‘: Past Identity Becomes Present Political Statement“. Balkan Insight (blog). 10.9.2020. https://balkaninsight.com/2020/09/10/living-yugoslavia-past-identity-becomes-present-political-statement/.

Çavolli, Nita. 2012. A City Surprised: An Analysis of Visual Content and Public Debate, „Skopje 2014“. Master's Thesis, Skopje: New York University, Faculty of Communication and Media Studies. https://www.academia.edu/4717921/A City Surprised An Analysis of Visual Content and Public Debate Skopje 2014.

Dimitrov, Slavcho. 2019. „Coalition MARGINS | SKOPJE PRIDE WEEKEND 2019 - GLITTERING WOUNDS“. http://coalition.org.mk/skopje-pride-weekend-2019-glittering-wounds/?lang=en.

Dimova, Rozita. 2013. Ethno-Baroque: Materiality, Aesthetics, and Conflict in Modern-Day Macedonia. New York: Berghahn Books. 
Dimova, Rozita. 2019. „Elusive Centres of a Balkan City: Skopje between Undesirable and Reluctant Heritage“. International Journal of Heritage Studies 25 (9), 958-973. https://doi.org/10.1080/13527258.2018.1482473.

Douglas, Mary. 2005. Purity and Danger: An Analysis of Concept of Pollution and Taboo. Routledge Classics. London, New York: Routledge.

Forty, Adrian, Küchler, Susanne, eds. 2001. The Art of Forgetting. Reprinted. Materializing Culture. Oxford: Berg.

Foster, Hal, ed. 2002. The Anti-Aesthetic: Essays on Postmodern Culture. New York: New Press.

Gell, Alfred. 1992. „The Technology of Enchantment and the Enchantment of Technology". Anthropology, Art and Aesthetics, edited by Jeremy Coote and Anthoony Shelton, 40-66. Oxford: Clarendon.

Gouma-Peterson, Thalia, Mathews, Patricia. 1987. „The Feminist Critique of Art History“. The Art Bulletin 69 (3), 326. https://doi.org/10.2307/3051059.

Graan, Andrew. 2013. „COUNTERFEITING THE NATION? Skopje 2014 and the Politics of Nation Branding in Macedonia“. Cultural Anthropology 28 (1), 161-179. https://doi. org/10.1111/j.1548-1360.2012.01179.x.

Hofman, Ana. 2020. „Disobedient: Activist Choirs, Radical Amateurism, and the Politics of the Past after Yugoslavia“. Ethnomusicology 64 (January), 89. https://doi. org/10.5406/ethnomusicology.64.1.0089.

Jakov Marusic, Sinisa. 2016. „Macedonians Mock Ruling Party’s Soviet-Style Art“. Balkan Insight (blog). 6.6.2016. https://balkaninsight.com/2016/06/06/macedonia-rulingparty-teased-for-commie-paintings-06-03-2016/.

Janev, Goran. 2015. „Skopje 2014: Instrumentalizing Heritage for Unexpected Results“. Cultures of History Forum, April, 23225 KB.https://doi.org/10.25626/0038.

Janev, Goran. 2017. „Burdensome Past: Challenging the Socialist Heritage in Macedonia“. Studia Ethnologica Croatica 29, 149-170.https://doi.org/10.17234/SEC.29.8.

Jovanovik, Gjorgje. „Gjorgje Jovanovik/ Menu“. n.d. http://www.gjorgiejovanovik.com/jovanovik-\%20menu.htm. Пристапено на: 12.5.2021. 


\section{ЕтноАнтропоЗум}

Kertzer, David. 1988. Ritual, Politics and Power. Yale: University Press.

Kolozova, Katerina, Borovska, Viktorija, Lechevska, Kalina, Sadiku, Artan, Blazeva, Ana, Aleksovski, Risto. 2013. „Who owns Alexander the Great? A Question upon EU Enlargement Relies“. Skopje: Institute of Social Sciences and Humanities. https:// www.academia.edu/5021198/Who owns Alexander the Great A Question upon EU Enlargement Relies

Koteska, Jasna. 2011. „Troubles with History: Skopje 2014“. ARTMargins. 29.12.2011. https://artmargins.com/troubles-with-history-skopje-2014/.

Korsmeyer, Carolyn, Brand Weiser, Peg. 2021. „Feminist Aesthetics“. The Stanford Encyclopedia of Philosophy, edited by Edward N. Zalta, Spring 2021. Metaphysics Research Lab, Stanford University. https://plato.stanford.edu/archives/spr2021/entries/feminism-aesthetics/.

Lefebvre, Henri. 2011. The Production of Space. Nachdr. Malden, Mass.: Blackwell.

Marchevska, Elena. 2017. „Performing the Present, Saving the Future: Digital Media Presence in the Work of Raspeani Skopjani“. Contemporary Theatre Review 27 (3), 391397.https://doi.org/10.1080/10486801.2017.1343240.

Marchevska, Elena, Çavolli, Nita, Jakimovska, Jana, Mojanchevska, Katerina. 2017. „Fluidity and Friendship: The Choir That Surprised the City“. Interventions, 2017.https:// www.contemporarytheatrereview.org/2017/raspeani-skopjani/.

Mattioli, Fabio. 2014. „Unchanging Boundaries: The Reconstruction of Skopje and the Politics of Heritage“. International Journal of Heritage Studies 20 (6), 599-615. https:// doi.org/10.1080/13527258.2013.818569.

Milevska, Suzana. 1998. „Female Art through the Looking Glass“. n.paradoxa 7. Edited by Katy Deepwell. July 1998. https://www.ktpress.co.uk/pdf/nparadoxaissue7_Suzana-Milevska_38-41.pdf?

Milevska, Suzana. 2006. „Naming And Urgency“. E-cart 7, March 2006. http://www.e-cart. ro/7/suzana/uk/g/suzana- uk.htm

Milevska, Suzana. 2010. Gender Difference in the Balkans Archives of representations of gender difference and agency in visual culture and contemporary art in the Balkans. Zurich: Lars Müller Publishers https://nbn-resolving.org/urn:nbn:de:101:1-2010052622957. 
Milevska, Suzana. 2013. „With Special Thanks To: A Balkan Curator in First Person Feminine“. http://www.openspace-zkp.org/2013/en/journal.php?j=3\&t=9.

Mulvey, Laura. 1989. Visual and Other Pleasures. London: Macmillan.

Plostad Sloboda. 2010. Ona se budi - 8-mo martovski raspeani skopjani.wmv.https://www. youtube.com/watch?v=GiQql7CHZZM.

Radisic, Danica. 2014. „Balkan Nationalists Bring Back Personality Cults in Tattoos of Ruling Politicians“. Global Voices (blog). 9.11.2014. https://globalvoices.org/2014/11/09/ balkan-nationalists-bring-back-personality-cults-in-tattoos-of-ruling-politicians/.

Risteski, Ljupčo. 2016. „Monuments and Urban Nationalism. The Skopje 2014 Project“. Antropologija 3, 49-70.

Rogoś, Agata Anna. 2019. „Old Boundaries and New Cultural Landscapes of a Multiethnic City in Modern-Day Macedonia“. Colloquia Humanistica, no. 8 (November), 221-246. https://doi.org/10.11649/ch.2019.014.

„Skopje 2014 Uncovered“. n.d. http://skopje2014.prizma.birn.eu.com/en. Пристапено на: 20.5.2021.

„Skopje Pride 2019 - Solidarity, Equality, Freedom“. 2019. Helsinki Committee for Human Rights. 1.7.2019._https://mhc.org.mk/en/news-en/skopie-pride-2019-solidarityequality-freedom/.

Sontag, Susan. 2002. Illness as Metaphor and AIDS and Its Metaphors. Reprinted in Penguin classics. Penguin Modern Classics. London: Penguin Books.

Stefoska, Irena, Stojanov, Darko. 2017. „A Tale in Stone and Bronze: Old/New Strategies for Political Mobilization in the Republic of Macedonia“. Nationalities Papers 45 (3), 356-369.https://doi.org/10.1080/00905992.2017.1308346.

Stojanovski, Philip. 2016. „Macedonia’s Ruling Party Has Resuscitated Socialist Realism Without the Socialisms“. Global Voices (blog). 3.6.2016. https://globalvoices. org/2016/06/03/macedonias-ruling-party-has-resuscitated-socialist-realism-without-the-socialism/.

Tera TV. 2019. Tv Tera Bitola Bitolska Parada Na Gordosta 0107 2019. https://www.voutube. com/watch?v=Dnkoop3sxiI. 
Tsagarousianou, Roza. 1995. „'God, Patria and Home‘: 'Reproductive Politics' and Nationalist (Re)Definitions of Women in East/Central Europe“. Social Identities 1 (2), 283295.https://doi.org/10.1080/13504630.1995.9959437.

Vangeli, Anastas. 2011. „Nation-building ancient Macedonian style: the origins and the effects of the so-called antiquization in Macedonia“. Nationalities Papers: The Journal of Nationalism and Ethnicity, 39:1, 13-32.

Veljanovska, Elena. 2018. „The Heroines of our Time“. The Heroines of our Time, exhibition catalogue. Skopje: Museum of the City of Skopje.

Véron, Ophélie. 2015. Deconstructing the Divided City: Identity, Power and Space in Skopje. Thesis (Doctoral), London: UCL (University College London).https://discovery.ucl. ac.uk/id/eprint/1470032.

Véron, Ophélie. 2017. „Challenging Neoliberal Nationalism in Urban Space: Transgressive Practices and Spaces in Skopje“.https://www.academia.edu/26740888/Challenging Neoliberal Nationalism in Urban space Transgressive Practices and Spaces in Skopje.

Zajovic, Stasa. n.d. „Everything for Peace, Health and Knowledge, Nothing for Armament - Žene u Crnom“. http://zeneucrnom.org/en/20-aktivnosti/bezbednost/1549-everything-for-peace-health-and-knowledge-nothing-for-armament. Пристапено на: 8.6.2021.

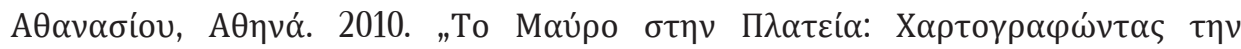

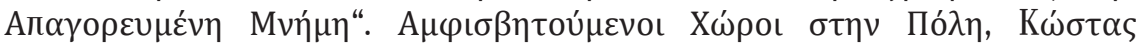

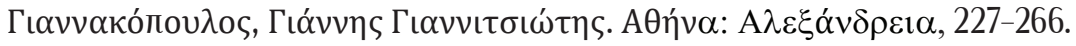

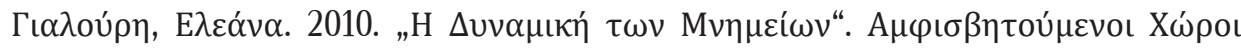

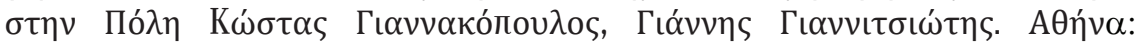
$\mathrm{A} \lambda \varepsilon \xi \dot{\alpha} v \delta \rho \varepsilon 1 \alpha, 329-389$.

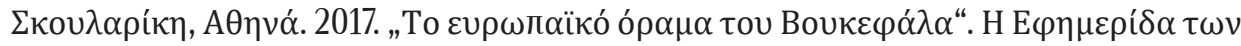

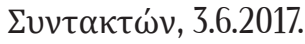

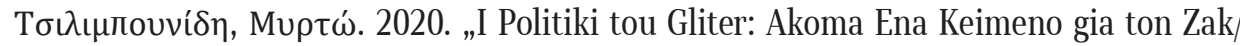
ti Zackie“. Queer Politiki Dimosia Mnimi. 30 Keimena gia ton Zak, edited by Athina Athanasiou, Grigoris Gougousis, Dimitris Papanikolaou. Athens: Rosa Luxemburg Foundation, 43-50. https://rosalux.gr/sites/default/files/publications/rosalux queerpolitics.pdf 
ЕтноАнтропоЗум

Илустрации

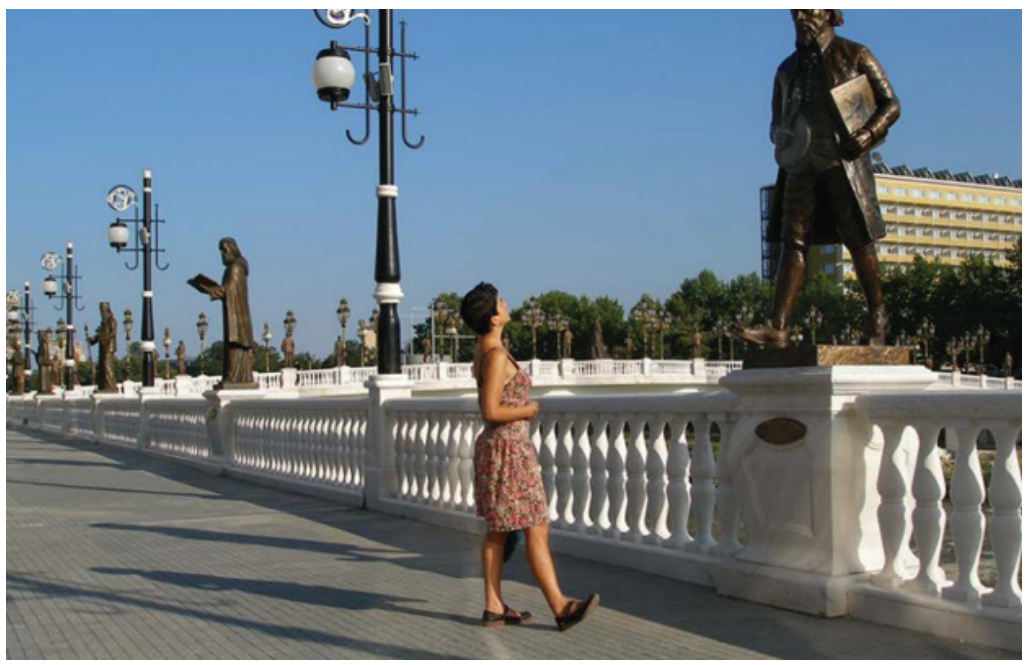

Слика 1

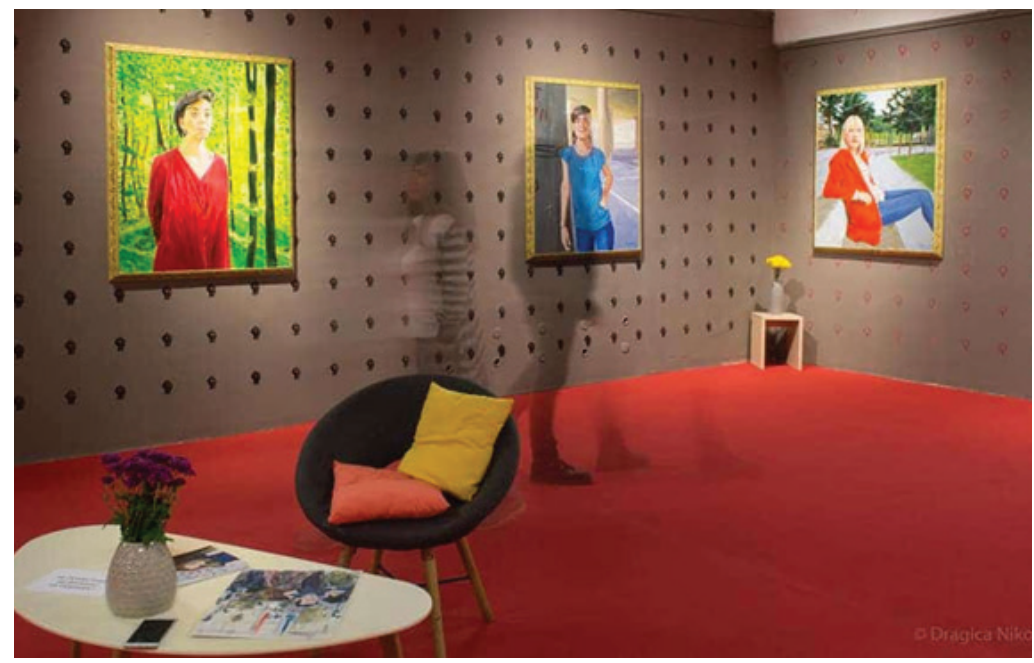

Слика 2 


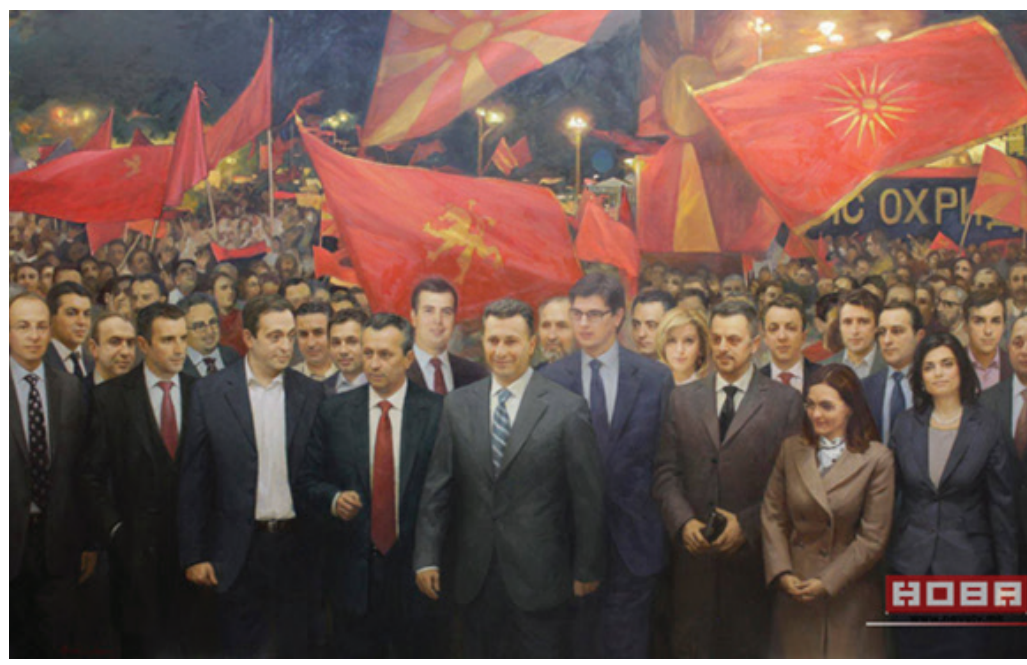

Слика 3

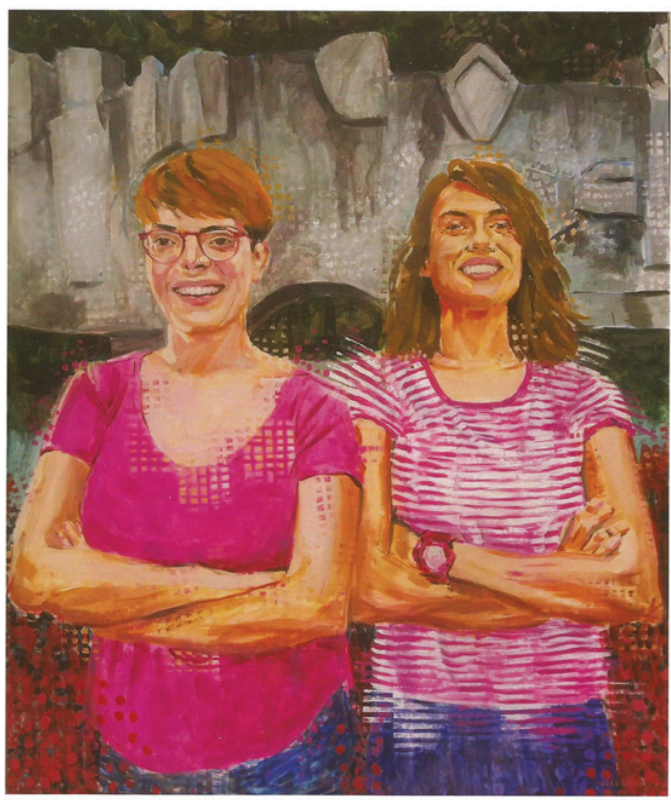

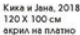

Слика 4 - од каталогот на изложбата 
ЕтноАнтропоЗум

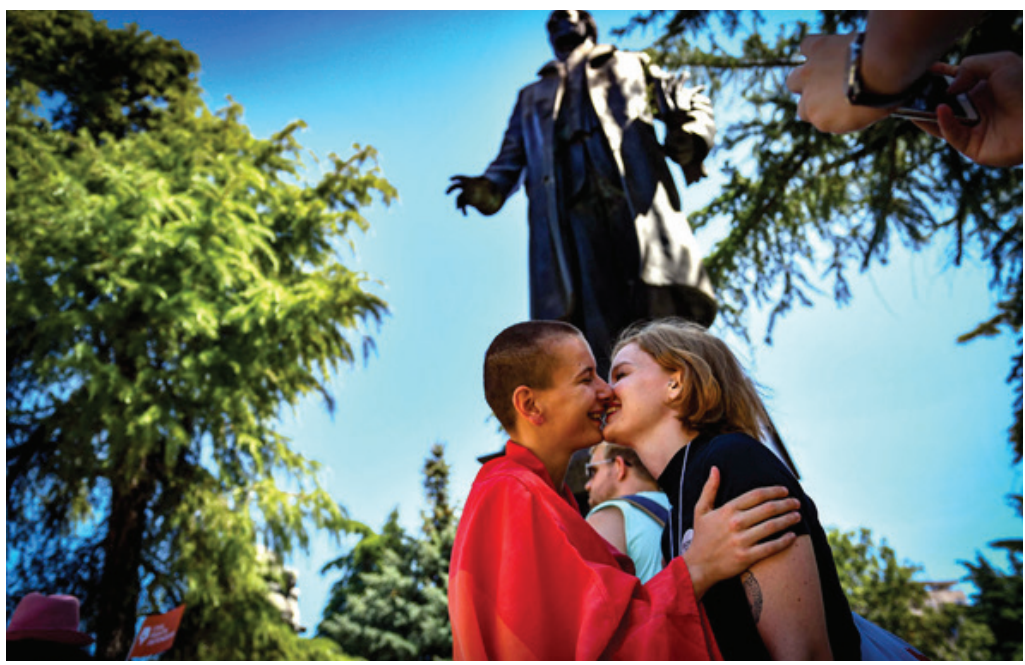

Слика 5 